\title{
Variações imaginárias e símbolo religioso: aproximações hermenêuticas
}

\author{
Imaginary variations and religious symbolism: \\ Hermeneutical approaches
}

\section{Variaciones imaginarias y símbolo religioso: enfoques hermenéuticos}

\author{
Vitor Chaves de Souza* \\ Ana Beatriz de C. dos S. Alexandrini**
}

\begin{abstract}
RESUMO
O artigo propõe uma aproximação temática a respeito do imaginário e do símbolo nos estudos em religião por um viés hermenêutico. Para isso, pensa-se acerca do valor das imagens gestadas no imaginário e materializadas em símbolos tendo neles uma fonte original de conhecimento. Considerando alguns interlocutores Gilbert Durand e Jean-Jacques Wunenburger, trabalharemos, para isso, uma aproximação teórica a partir da percepção e da imaginação em David Hume abarcando a proposta hermenêutica a respeito do estudo das imagens e símbolos na religião segundo, sobretudo, a obra Imagens e Símbolos, de Mircea Eliade. Tal proposta procurará resgatar a sobrevivência das imagens primordiais no subconsciente bem como os valores arcaicos preservados nos símbolos culturais e fundantes das sociedades que constituem o imaginário de uma determinada cultura.

Palavras-chave: imaginário; símbolo; percepção; David Hume; Mircea Eliade.
\end{abstract}

\begin{abstract}
The paper proposes a thematic approach regarding the imaginary theme and the symbol studies on hermeneutics of religion. For this task, the value of images formed in the imaginary and materialized in symbols is considered as an original source of knowledge. Having some interlocutors, such as Gilbert Durand and Jean-Jacques Wunenburger, the paper starts with a theoretical approach on the theme of perception and imagination in David Hume. It also covers the hermeneutic proposal regarding the study of images and symbols in religion mainly according to Mircea Eliade's Images and Symbols. Such proposal seeks the survival of primordial images in the subconscious as well as the archaic values preserved in cultural and founding symbols of the socie
\end{abstract}

Keywords: imaginary; symbol; perception; David Hume; Mircea Eliade.

\section{RESUMEN}

El artículo propone un enfoque temático con respecto al imaginario y el símbolo en los estudios de religión a través de un sesgo hermenéutico. Para esto, se piensa en el valor de las imágenes generadas en el imaginario y materializadas en símbolos que tienen en ellas una fuente original de conocimiento. Considerando a algunos interlocutores Gilbert Durand y Jean-Jacques Wunenburger, trabajaremos, para esto, un enfoque teórico desde la percepción e imaginación en David Hume cubriendo la propuesta hermenéutica sobre el estudio de imágenes y símbolos en la religión según, la obra Imágenes y símbolos, de Mircea Eliade. Dicha propuesta buscará rescatar la supervivencia de imágenes primordiales en el subconsciente, así como los valores arcaicos preservados en los símbolos culturales y fundadores de las sociedades que constituyen el imaginario de una cultura dada.

Palabras claves: imaginario; símbolo; percepción; David Hume; Mircea Eliade. 
Nada pode ser apreendido em sua perfeição e sua totalidade.

A pintura do mundo sempre é inexata.

Não passa, de resto, de uma pintura de escritor. Tenho en porventura o poder de exprimir a verdadeira realidade?

Virginia Woolf

\section{Introdução}

O tema da imagem nos estudos da religião, a despeito dos avanços da Cultura Visual enquanto disciplina do conhecimento - que procura um conhecimento autêntico a partir da construção social da experiência visual -, remete, para uma abordagem hermenêutica, aos fundamentos da origem das sociedades. Segundo a filosofia clássica, o conhecimento começa na percepção visual do mundo. Na República, Platão assume a visão, ópsis, como o processo inicial do conhecimento, tendo no olho as características, logo de início, como phosphóra: "o que leva ou o que dá a luz". (HADDAD, 2008, p. 7). Para os medievais, as pinturas traduziam conhecimento e saberes teológicos compreensíveis pela experiência visual e a mediação de mundo. $\mathrm{Na}$ atualidade, a imagem, pela sua evolução dos aparelhos de produção e técnicas (cf. FLUSSER, 2009, p. 9-12), saiu dos domínios das instituições medievais para abarcar todas as áreas do conhecimento. Não apenas as imagens estéticas, mas também as imagens geradas na mente, como ideias ou ideações, passam a ser objeto de reflexão, tanto da técnica como da codificação dos valores implícitos nos conteúdos imagéticos.

Em suma, pode-se abordar a ficção primordial da imagem em perspectivas socialmente aceitas, dogmas oficialmente estabelecidos ou ritos inquestionados para demostrar um movimento de ficção original também nestas narrativas pretendidas. Perguntamos, para introduzir o tema da variação imaginária de imagens religiosas, pelo papel da imaginação no universo religioso. Mediante tal pergunta, pensamos a imaginação como algo inconfundível, digno de estudo e avaliação em sua autonomia e na sua manifestação enquanto fenômeno nos quadros históricos e predicados filosóficos que compõem o imaginário, como uma antiga extração dos fragmentos e imaginários religiosos primordiais. A partir deste escopo, uma proposta temática e metodológica se apresenta, tendo na hermenêutica a aproximação proposta e em Mircea Eliade o seu principal expoente metodológico. O percurso da reflexão, portanto, começa pelo imaginário, abrindo-se o tema metodologicamente, seguindo a linha hermenêutico- 
metodológica da Universidade de Chicago (KITAGAWA, 1959, p. 34), para uma dialética entre imagem e símbolo, tendo, então, a reflexão da variação imaginária na religião como o mais profundo valor simbólico.

\section{Imaginário}

O tema da imagem, a rigor, não é assunto simples de ser lidado, visto que, para muitos teóricos, a depender da abordagem, a imagem participa mais da subjetividade do que qualquer pretensão objetiva. De fato, a subjetividade inerente à imagem é a sua característica mais original, uma vez que tendo começado na imaginação, a imagem reflete um conhecimento ideal no mundo exterior sensível. Para uma abordagem hermenêutica do imaginário, faz-se necessária uma certa legitimidade científica do tema. Por isso, para não cairmos em contradição, optamos, primeiro, pela reflexão do imaginário e da imaginação como formadores de conhecimento humano.

Para Eliade, “a imaginação não é uma invenção arbitrária; etimologicamente, é relativo a imago, 'representação, imitação', e a imitor, 'imitar, reproduzir'. A imaginação imita modelos exemplares - 'imagens' reatualizando-os, repetindo-os mais e mais" (ELIADE, 1988, p. 156). O poder da imaginação é fundamental para a articulação do conhecimento humano, sobretudo na esfera das artes e, principalmente, da religião. A despeito da variedade de apreciações - ou negações - das imagens, não deveríamos cair na tentação de rejeitar a sua função cognitiva. Segundo Eliade - e aqui outros teóricos compactuam com ele, cf. Gilbert Durand, Wolfgang Iser ou Vilém Flusser -, até "a mais apagada existência está pejada de símbolos, o homem mais 'realista' vive de imagens” (ELIADE, 2004, p. 17). A imagem permeia a humanidade, desde as sociedades mais primitivas até os tempos atuais. Imagens para explicar, imagens para fazer sentir, imagens para ser apenas imagens, imagens que falam sobre o eu e o tu, sobre o mundo e aquilo que está fora dele, imagens que silenciam.

Segundo Wolfgang Iser, em O Fictício e o Imaginário, o imaginário precisa ser ativado (ISER, 1999, p. 66-67), ou seja, precisa ser praticado, visto que não se trata de uma faculdade isolada nem autônoma, mas subordinada a discurso específico, e, por isso, é preciso ser colocado em ato juntamente com a sua intenção de imaginação. Logo, o imaginário é ato. Enquanto ato, participa de uma função cognitiva na qual a ação e o conhecimento estão diretamente vinculados. O discurso específico do imaginário remete a uma forma de conhecimento próprio, já antecipado por Aristóteles, David Hume e, por fim, por Immanuel Kant, retomado pelos críticos literários na 
contemporaneidade. A título de exemplo, Northrop Fry situa na literatura o produto do imaginário par excellence (FRYE, 2004, p. 23). Não por acaso, Eliade escreverá em seus diários acerca de uma necessidade existencial para narrativas, mitos e sonhos. Tal necessidade, segundo ele, é praticamente orgânica, ou seja, é natural da condição humana inclinar-se para as narrativas primordiais e cheias de significados. Afinal, escreveu Eliade no seu terceiro diário, "os universos imaginários criados nas novelas, estórias e contos revelam certos valores e significados únicos para a condição humana que, sem tais narrativas, ficariam desconhecidos ou, pelo menos, compreendidos imperfeitamente" (ELIADE, 1989, p. 283). O imaginário, seguindo a tradição hermenêutica dos textos e estudos religiosos, não deve ser desconsiderado da reflexão - e pode, inclusive, ser o ponto inicial da aproximação entre imagem e símbolo religioso.

O imaginário, portanto, carece de um trabalho e um direcionamento (ISER, 2013, p. 2). Deste modo, o imaginário não imagina por si: ele é moldado. Não se trata de uma atividade ativa, mas passiva para si próprio. Uma afirmação de Freud, citada por Wolfgang Iser, muito elucida sobre isso, a saber: "sei a imaginação criadora de fato incapaz de inventar o que quer que seja, só podendo combinar componentes estranhos um ao outro'. O imaginário precisa, portanto, de um meio para realizar o que esse mesmo meio pretende que o imaginário faça” (ISER, 1999, p. 73; 2013, p. 7). Evidentemente a nossa intenção é mais aproximativa do que definitiva, isto é, aproximamo-nos do tema considerando o que muito foi exposto na história do pensamento ocidental a respeito para uma contextualização mais eficiente. Neste sentido, o imaginário apresenta-se como algo feito de forma secundária, partindo das ideias e das impressões que uma pessoa pode ter ao longo da vida. Tais ideias e tais impressões não precisam de complexidade: enquanto imagens, elas podem ser simples e diretas, caso não possuam discrição ou separação complexas (VALADARES, 2009, p. 253).

A este respeito, é indispensável recorrer a David Hume - talvez, o filósofo que mais se incomodou com a imaginação na Modernidade. Se Platão restringiu o uso da imagem na filosofia para abordar questões complexas e relevantes (tendo na variedade de imagens, por exemplo, o eikon e o eidolon, aspectos negativos de uma possível substituição da precisão das palavras), é importante reconsiderar a posição platônica para alargar o papel da imagem na formação humana (CROMBIE, 1967, p. 3-4). Em relação a isso, portanto, Hume apresenta-se como um ponto de partida interessante no aspecto de uma certa positividade da imagem e, consequentemente, da imaginação. Pioneiro na inserção da percepção humana na filosofia, 
Hume pretendia um sistema de pensamento que desse conta não apenas dos argumentos dedutivos - isto é, aqueles que partem da razão -, mas também dos argumentos intuitivos: aqueles que partem da experiência. Logo, a experiência, para Hume, é tão importante quanto o conhecimento filosófico. Para ele, "todos os argumentos sobre questões de fato baseiamse na relação de causa e efeito, cujo conhecimento depende inteiramente da experiência" (CONTE, 2010, p. 8).

O tema da experiência coloca a percepção no centro da reflexão ao invés de privilegiar puramente a razão. Em outras palavras, a percepção é primeira, não a razão. Logo, a existência, para Hume, é a vivência das próprias percepções. E o que isso tem a ver com o tema do imaginário? Sendo o início do conhecimento humano a percepção, essa intuição de mundo é trabalhada, sobretudo, na tarefa da imaginação. A imaginação é o espaço no qual o conhecimento é gestado e gerido. A percepção - o nosso elo vital com o mundo - traduz o contato do sujeito com o mundo em impressões (HUME, 2004, p. 73). As impressões são primeiras e fundantes. Trata-se de uma categoria humeana para designar a forma mais original de conhecimento. Na sequência, posterior às impressões, há as ideias. O que há de original aqui, diferente de Descartes, é a assunção de um conhecimento variado em simples e complexo dada a experiência sensível com o mundo. A percepção oferece uma impressão imediata e simples. Essa impressão pode orientar o conhecimento na direção de uma ideia, na qual o mundo é organizado. A experiência desenvolve movimentos constantes de impressões e ideias, qualitativamente diferentes e distintas, configurando um conhecimento próprio. A esse respeito, Alexandre Arbex Valadares elucida:

Isto significa que a mente opera com impressões e ideias complexas e que as ideias simples só existem nela já associadas umas às outras. A imaginação pode entremeá-las em variadas combinações, mas nunca as conceber separadamente, porque tende, por certas propriedades originais de sua natureza, a associar as ideias segundo determinadas relações. A imaginação passa de uma a outra ideia irresistivelmente, e prescinde, nesse movimento, do concurso do raciocínio; a associação de ideias na imaginação é précognitiva (VALADRES, 2009, p. 254).

Há uma interação entre as impressões e as ideias, sejam-nas simples ou complexas, de modo que as simples só existem associadas às outras complexas, formando, assim, um conhecimento. Ora, e a imaginação? A imaginação, neste momento, é o espaço no qual as relações são operadas, criando algo que conceba sentido às ideias percebidas. Ainda assim, segundo aponta Alexandre Valadares, ter ciência de que as ideias simples são uma 
unidade invariante da mente, elas não podem por si só revelar a constância e a uniformidade da imaginação: o que revela essa constância é o mecanismo de interação das ideias simples geradores de ideias complexas. Sem esse mecanismo e essa constância de criação, a humanidade viveria em um caos, não podendo manter nenhuma regularidade nos assuntos - e poderiam encontrar algum diálogo apenas por acaso, quando aleatoriamente as ideias se encontrassem, simples ou complexas.

As ideias são-nos dadas como imagens de impressões imediatas, mas podemos formar, a partir dessas ideias primárias, ideias secundárias — ideias de ideias — que introduzem na imaginação outra qualidade de percepção: a imaginação opera uma alucinação em segundo grau das ideias em relação às impressões imediatas. Por esse movimento, as ideias abstraem suas impressões originais e assumem a forma de efeitos espontâneos da mente. As impressões produzem imagens de si mesmas — as ideias —, e estas, apresentadas à mente como novos objetos de percepção, imprimem nela novas ideias, que reproduzem as primeiras, tal como estas reproduzem as impressões primárias (VALADRES, 2009, p. 256).

Há um parâmetro no qual a imagem é formada pelas percepções das coisas e das ideias que fazemos destas coisas. Desta forma, para Hume, no registro histórico das experiências dos povos as paixões humanas parecem manifestar-se sob formas regulares, reiteradas em padrões afetivos que, ao andar dos tempos, se conservam idênticos em sua tendência geral. É nesta tendência geral que os símbolos religiosos se encontram, que as imagens sagradas são formuladas. As ideias - e todos produtos culturais, incluindo as imagens e símbolos religiosos - formadas no imaginário surgem das impressões no mundo sensível para a configuração de um conteúdo internamente compreendido e externamente comunicável. Não aprofundaremos o imaginário religioso no pensamento de Hume - até mesmo porque a crítica de Hume à religião vai na direção do empirismo e da religião reformada escocesa -, mas partiremos da noção de imaginário proposta por Hume: o lugar da relação causal dos objetos (cf. HUME, 2009, p. 102). Sendo o imaginário o lugar original e originário de conhecimento, falar de imaginário religioso e, consequentemente, variações imaginárias, a partir deste espaço criativo de conhecimento, desapegado de dogmas e crenças, torna-se possível compreender mais largamente o papel das imagens e símbolos na religião. Tal é a direção de autores como Gilbert Durand e Mircea Eliade.

Aqui o imaginário é apresentado como um lugar de "entre saberes" (DURAND, 1996, p. 215-27). É esse entre saber que interessa ao estudo das imagens e símbolos religiosos. Afinal, na substituição de possíveis mundos inteligíveis, as imagens representam um ideal e os símbolos procuram juntar 
algo que estaria primeiramente perdido. Neste sentido, as oposições como luz e sombra tornam-se complementares. Segundo Gilbert Durand, em seu livro $O$ imaginário, não apenas a luz da percepção imediata funciona o pensamento humano, mas também as ideias e as experiências vagueiam nas sombras do subconsciente. Isto significa: nem sempre a lógica, nem apenas a razão - a capacidade de geração de imagens irracionais em estados oníricos, levando a possíveis criações poéticas, ou até mesmo a grandes neuroses infundadas, é a direção da interpretação dos sentidos abstratos e inconscientes. Durand é influenciado por Sigmund Freud a respeito das percepções por meio de experiências em divã terapêutico, concluindo que as imagens afloram do inconsciente, do psiquismo, oferecendo à consciência uma série de informações não tangíveis pela razão. Deste modo, toda manifestação imagética, de alguma forma mostra uma interação entre algo inconsciente ainda não esclarecido, desembocando em uma tomada de consciência ativa, desta forma, algo antes obscurecido pelo subconsciente, ou ainda não esclarecido de forma compreensível, toma forma de símbolo, capaz de organizar uma linha de pensamento clara, possibilitando o entendimento de algo antes ofuscado, as coisas e os pensamentos passam a fazer sentido lógico (DURAND, 1998, p. 35-36). Durand destaca o psiquiatra suíço Carl-Gustav Jung quanto ao que diz respeito ao lugar da imagem na constituição do saber psíquico: ele normalizon o papel da imagem. Para Jung, a imagem, por sua própria construção, é um modelo de autoconstrução (ou de individuação) da psiqué (DURAND, 1998, p. 37). Uma construção feita para que experiências e percepções se tornassem inteligíveis. Vale ressaltar que os antigos e as sociedades arcaicas viviam em constantes estágios de êxtases, não diferenciando muito bem as experiências religiosas das imagens primordiais de sonhos (cf. Mircea Eliade desenvolveu em sua obra Xamanismo).

\section{Imagens simbólicas}

Onde essas ideias e percepções transformam-se em imagens? JeanJacques Wunenburger trabalha a questão na seguinte direção:

as imagens são realidades que se configuram no espaço e no tempo, mental e exterior. Na imagem animada, o tempo cinematográfico não é o tempo da vida, mas esse tempo de um filme procura restituir um tempo da história, um tempo do mundo. Da mesma forma, o espaço das imagens digitais é, cada vez mais, sem dúvida, multidimensional, e não é o mesmo que o espaço real no qual o corpo encontra os objetos, encontra a fadiga, encontra o sofrimento. Fenomenologicamente, portanto, tem-se uma verdadeira transmutação espaço-temporal entre a vida e as imagens. É interessante, pois, observar como esse espaço-tempo das imagens é capaz de imitar o espaço-tempo da vida; 
porém, mais do que imitar, esse espaço-tempo das imagens é capaz de fornecer uma abordagem muito mais densa e intensa. É por isso que nós preferimos, muitas vezes, o mundo das imagens ao mundo da realidade, um romance à vida, um filme à realidade (WUNENBURGER, 2013, p. 312).

Conforme supracitado, as imagens possuem um poder próprio. Poderíamos referenciar esse poder a uma transcendência da realidade. Assim sendo, a imagem é como uma porta de entrada para as percepções antes inviáveis - ou até mesmo rememorações realistas. De certa forma, assim como bem ressalta o autor, a imagem é capaz de fazer com que a imaginação transcenda o comum e alcance, por meio de seu próprio produto - a imagem -, algo que toque o ser de forma relevante. Muitas vezes ultrapassa a cronologia comum, como o enredo de uma narrativa ou um filme, acompanhando a vivência das personagens em um tempo passado ou futuro. Tal interiorização só é possível de maneira catártica - o que seria quase que impossível de outra forma, gerando de certa forma, em algumas pessoas, uma predileção pelas imagens da vida fictícia a despeito dos desafios da vida real.

A imagem, portanto, em sua constituição original, revela algo. Se ela revela, ela também guarda e preserva, uma vez que pode produzir empatia ou até mesmo resistência em seus assuntos preservados. A imagem, neste sentido, pode ser uma imagem de representatividade sensível ou representatividade intelectual. Um bom uso da imagem transita pelos domínios da reflexão e da sensibilidade. Jean-Jacques Wunenburger, por este motivo, afirma que a imagem nos toca e provoca nossos afetos. Para ele, a imagem opera e, principalmente, "produz uma dialética entre afeto e representação. A representação é o espelho do afeto. Mas sabe-se como a representação modifica os afetos." (WUNENBURGER, 2013, p. 312) Para o autor, a originalidade da imagem está na sua capacidade de informar e sensibilizar ao mesmo tempo. Por isso, as imagens, segundo Wunenburger, operam em três momentos: como uma manifestação espaço-temporal no caráter fenomenológico; como uma manifestação afetiva; como uma dimensão de significado de mundo. Logo, a imagem mostra o que ela é, de fato, quando ela percebida, assimilada e vivida. A imagem doa sentido na medida em que produz sentimento e traz consigo algum significado (WUNENBURGER, 2013, p. 313).

O imaginário - o lugar da criação das imagens e dos símbolos religiosos, bem como de todo o saber filosófico (na direção de Hume) - é impregnando de significado, valor e de ideias. Assim sendo, o imaginário, para Wunenburger (2013, p. 317), tem o poder de apresentar ao ser humano uma fonte psíquica relevante, visto que há uma tarefa de revelação do ser no mundo. A imaginação é a porta de entrada para novas descobertas, 
para além da razão, a despeito dos sistemas de signos potencialmente tão ricos e eficazes gerados pela lógica filosófica ou pelas categorias científicas. Retomando novamente Hume para fundamentar esta virada reflexiva, as impressões oriundas da percepção do mundo sensível geram ideias - e destas ideias, podendo ser simples ou complexas, concernem a uma mesma percepção para a gestação do conbecimento. Em outras palavras, o conhecimento, seja ele filosófico, científico ou religioso, quando iniciado pela e na imagem, trata de significações humanas enquanto presença de algo percebido no mundo exterior. As ideias, portanto, derivam das impressões e ambas se referem à mesma substância: o conhecimento humano. No caso do imaginário religioso, o saber original gerado é encontrado na polissemia do símbolo sagrado (cf. ELIADE, 2004, p. 65).

É importante frisar neste estágio de nossa reflexão: o mesmo sistema que gera impressões e ideias promove o trabalho dos símbolos religiosos nas variações imaginárias de mundo. Imagens e símbolos estão diretamente correlacionados, pois são formados no mesmo espaço - o imaginário - e possuem a mesma estrutura: comunicam o incondicional (TILLICH, 1973, p. 30); comunicam aquilo que não poderia ser dito de outra maneira senão imageticamente ou simbolicamente (ELIADE, 2004, p. 78). Há uma sabedoria implícita nas imagens e símbolos religiosos e o trabalho da interpretação dessas produções abre um horizonte de sentido para a compreensão vivencial destas produções. Afinal, o símbolo religioso, segundo Tillich, é uma tentativa de superar a "limitação de nossa função cognitiva" (TILLICH, 1973, p. 178). Assim sendo, se algo não pode ser dito de outra maneira a não ser simbolicamente, não se trata de uma limitação humana, mas da superação da própria condição humana - agora expressada simbolicamente. Por essa e outras razões a filosofia contemporânea se debruçou numa abordagem hermenêutica do símbolo para a compreensão do que é próprio do humano. Ernst Cassirer, por exemplo, em sua obra Filosofia das Formas Simbólicas, assume que "deveríamos definir o homem como animal symbolicum e não como rationale" (CASSIRER, 1975, p. 163).

[...] há de entender-se aqui toda a energia do espírito em cuja virtude um conteúdo espiritual de significado é vinculado a um signo sensível concreto e lhe é atribuído interiormente. Neste sentido, a linguagem, o mundo mítico-religioso e a arte se nos apresentam como outras tantas formas simbólicas particulares (CASSIRER, 1985, p. 163).

Na mesma linha, Jean-Jacques Wunenburger declarou: "tudo o que o espírito humano produz é simbólico. Nós podemos falar do mundo sem tocá-lo, o que é a característica da espécie humana, uma vez que os animais 
não têm ferramentas simbólicas. Eles não têm a mediação que permita substituir as coisas pela palavra" (WUNENBURGER, 2009, p. 314). Com isso, o que diferencia, de certo modo, os animais do ser humano, em parte, é esta capacidade imaginativa e a capacidade de gerar produtos culturais (como a linguagem) e religiosos (como a preocupação com a eternidade). $\mathrm{Na}$ mesma linha de pensamento, Eliade compreende que:

O pensamento simbólico não é domínio exclusivo da criança, do poeta ou do desequilibrado: ele é consubstanciai ao ser humano: precede a linguagem e a razão discursiva. O símbolo revela certos aspetos da realidade — os mais profundos — que desafiam qualquer outro meio de conhecimento. As imagens, os símbolos, os mitos, não são criações irresponsáveis da psiqué; eles respondem a uma necessidade e preenchem uma função: pôr a nu as mais secretas modalidades do ser (ELIADE, 2004, p. 13).

Como bem ressalta o autor, o pensamento simbólico é algo que precede as palavras; por suas formas de se revelar, o símbolo é capaz de traduzir alguns aspectos da realidade, algo que foge do padrão filosófico. E mais do que meras representações, os símbolos não são criados aleatoriamente; na verdade, respondem as necessidades de cada ser humano, preenchem lacunas antes insondáveis pela razão. O símbolo é, neste estágio da reflexão, a linguagem da religião; ao lado dos mitos, símbolos narram e apresentam uma história verdadeira com realidades sagradas; revela, em multivalência, diferentes níveis da realidade humana; o símbolo é um modo de cognição autônomo que, ao ser vivido, confere sentido à existência humana; e, assim, a metodologia de Eliade para o estudo da história e fenomenologia da religião coloca o símbolo religioso como parte fundante de sua hermenêutica. Portanto, "sendo o homem um homo symbolicus e estando o simbolismo implícito em todas as atividades, todos os fatos religiosos têm, necessariamente, um caráter simbólico" (ELIADE, 1999, p. 217). A religião, portanto, é puro ato simbólico em celebração.

Alargando o lugar do símbolo na tarefa do pensamento - e na religião -, no texto Chegando ao Inconsciente, que abre a célebre coleção "O Homem e seus Símbolos", Carl G. Jung define o símbolo como uma "imagem que nos pode ser familiar na vida diária, embora possua conotações especiais além do seu significado evidente e convencional. Implica alguma coisa vaga, desconhecida ou oculta para nós" (JUNG, 1977, p. 20). Por meio da imagem e do símbolo criado, pode-se alcançar compreensões antes ofuscadas na mente e agora possíveis de serem visualizadas e pensadas. Uma imagem passa a ser símbolo, segundo Jung, quando o significado existente nela transcende o significado imediato e óbvio. Deste modo, a mente, ao 
sondar a profundidade de um símbolo, é levada a novas percepções, novas impressões, novas ideias; é erguida na direção de algo que vai além da razão humana (JUNG, 1977, p. 20-21). A incapacidade de se explicar o insondável abre a reflexão para outras direções do pensamento, buscando a compreensão do insondável no sondável. Trata-se de impressões e ideias diretamente correlacionadas simbolizando uma realidade para aqueles e aquelas que a vivenciam. Ressalta, ainda, Carl G. Jung que as inúmeras e inexplicáveis situações de nosso dia a dia doam ao imaginário um repertório para a criação de novos símbolos e, frequentemente, o ser humano lança mão de símbolos para legitimar atitudes e conceitos. A religião, por tratar de aspetos sagrados e divinos, fundamenta a sua reflexão no simbólico, expressa-se por meio de símbolos e, com isso, as imagens presentificam parte de uma ideia daquilo a ser vivenciado (JUNG, 1977, p. 21-22).

A este respeito, Mircea Eliade, amigo de Jung e parceiro de reflexão no Círculo de Éranos (cf FERREIRA; SILVEIRA, 2015, p. 260), trabalhou a imaginação na direção de uma criatividade própria do humano, ao mesmo tempo verossímil e rica. "Ter imaginação é gozar de uma riqueza interior, de um fluxo ininterrupto e espontâneo de imagens" (ELIADE, 2004, p. 20). Mais do que apenas uma elaboração heurística, Eliade pretende um "despertar" da razão para as dimensões humanas esquecidas pela tradição filosófica. A imaginação, como bem resgatou Hume, não é secundária nem inferior a um possível conhecimento primeiro: a imaginação é o próprio conhecimento primeiro do mundo. Afinal, nela operam todas as faculdades sensoriais, as impressões de mundo, as ideias filosóficas e, principalmente, o universo imaginário religioso. Por isso Eliade - um autor fundamental para a compreensão dos estudos em imagens e símbolos religiosos - ousa em situar o cultivo das imagens e dos símbolos como um processo de autoconhecimento da humanidade voltada para si própria. As imagens primordiais e os símbolos mais importantes de uma determinada cultura podem dar a direção de uma compreensão mais profunda a respeito do devir humano. Em Imagens e Símbolos, Eliade escreveu:

"a imaginação imita modelos exemplares — as imagens — reprodu-las, reatualiza-as, repete-as sem fim. Ter imaginação, é ver o mundo na sua totalidade; pois o poder e a missão das imagens consistem em mostrar tudo o que permanece refratário ao conceito. Assim se explica a desgraça e a ruína do homem que 'não tem imaginação': ele está isolado da realidade profunda da vida e da sua própria alma” (ELIADE, 2004, p. 20-21).

Deste modo, pode-se entender que a imaginação capacita a tarefa compreensiva do humano além das possibilidades imediatas, além da razão 
constituída pela tradição e, sobretudo, transcendendo limites para a abertura de possibilidades. Cultivar a imaginação aproxima o ser do mundo. Tal cultivo carrega um poder recriativo, ressignificativo e, se quisermos, um poder de reavivamento daquilo que não é possível fora da imaginação. Aquele que ignora essas potencialidades estaria, segundo Jung e Eliade, refém de uma vida simplificada em uma única narrativa e, de certo modo, privada da realidade imposta a ela. Pois a realidade é a própria fonte do pensamento simbólico.

\section{Imagem e símbolos na religião}

Até aqui desenvolvemos uma aproximação temática destacando a primordialidade da percepção (Hume), a originalidade do imaginário (Wunenburger) e o desdobramento dos conteúdos imagéticos e simbólicos (Jung e Eliade) para o conhecimento religioso. Agora, pretendemos, como um sobrevoo, aprofundar uma metodologia de abordagem do imaginário religioso formado pelas imagens e símbolos sagrados. A este respeito fazse notar a centralidade de uma imaginação produtora de símbolos, pois inaugura a percepção dos sentidos para além dos condicionamentos e limites - a saber, a possibilidade da experiência com o divino, com o sagrado.

$\mathrm{Na}$ religião, o uso de imagens como fontes agregadoras de conceitos e impressões são costumeiramente utilizados, e didaticamente avançados. A representação de um mundo ideal não se limita às descrições letradas. Segundo Eliade, "a sabedoria popular tem frequentemente exprimido a importância da imaginação para a própria saúde do indivíduo, para o equilíbrio e riqueza da sua vida interior" (ELIADE, 2004, p. 13). O filósofo romeno das religiões quer nos alertar que a imaginação e as imagens e os símbolos formados pela faculdade imaginativa nos dão o que pensar: pensar com imagens, capazes de direcionar as vivências e os sentidos vividos de cada indivíduo. Por esta razão a dinâmica de um símbolo religioso ou os sentidos de uma imagem não deveriam ser esgotados por um julgamento prévio nem encerrados em uma única interpretação: afinal, se a imagem abre sentidos e o símbolo dá o que pensar (que é a conclusão de Ricoeur em A Simbólica do Mal), ambas instâncias promovem conhecimento humano e divino na tentativa de aproximação das polaridades da vida.

Cabe pensar, portanto, em passos metodológicos a respeito de como em uma sociedade moderna a crença em mitos, símbolos e imagens pode ainda se manter, tendo em vista um progresso dominante das narrativas que pretendem ser últimas. Principalmente nas religiões e seu histórico de conflitos e aliança com poderes para se manterem como o discurso oficial 
e a forma legítima de celebração cúltica (a este respeito, cf. História de Deus, de Karen Armstrong). É notório, segundo Jung e Eliade, perceber que desde as sociedades arcaicas muitas crenças se mantêm no inconsciente ainda hoje. Antigamente, as sociedades arcaicas eram fechadas em si mesmas e tudo o mais que ultrapassasse seus limites fronteiríssimos eram assumidos como natureza perigosa e bárbara, também demoníaca, tornando o desconhecido em inimigo, exterior à família. De certo, o insondável permeava caos, a morte e escuridão. Eliade exemplifica:

De fato, um grande número de textos assimila os adversários, prontos a atacar o território nacional, às larvas, aos demónios ou às forças do caos. Assim, os adversários do Faraó eram considerados como "filhos da ruína, dos lobos, dos cães”, etc. O Faraó era assimilado ao deus Rá, vencedor do dragão Apófis enquanto os seus inimigos eram identificados com este dragão mítico. Pelo fato de atacarem e porem em perigo o equilíbrio e a própria vida da cidade (ou ide qualquer outro território habitado e organizado), os inimigos são assimilados às forças demoníacas, pois eles esforçam-se por reintegrar este microcosmos no estado caótico, ou seja, suprimi-lo. A destruição de uma ordem estabelecida, a abolição de uma imagem arquetípica, equivalia a uma regressão para o caos, para o pré-formal, para o estado não diferenciado que precedia a cosmogonia. Notemos que as mesmas imagens são ainda utilizadas nos nossos dias quando se trata de formular os perigos que ameaçam um certo tipo de civilização: fala-se nomeadamente de "caos", de "desordem", das "trevas" em que mergulhará o "nosso mundo". Todas estas expressões, como bem se vê, significam a abolição de uma ordem, de um Cosmos, de uma estrutura, e a re-imersão num estado fluido, amorfo, caótico enfim. A concepção do adversário sob a forma de um ser demoníaco, verdadeira encarnação das forças do mal, sobreviveu igualmente até aos nossos dias (ELIADE, 2004, p. 37-38).

Conforme supracitado, inferimos uma fundamentação metodológica propensa para a compreensão do imaginário religioso diante das variações imaginárias do mesmo: desde a Antiguidade, o imaginário é permeado por valores, quais sejam, perigoso e confortável, ameaçador e confiável, familiar e estrangeiro. Na religião, os valores são interiorizados na esfera simbólica insondável, mantendo-se vital desde sociedades arcaicas e primitivas até o tempo presente. As imagens e os símbolos religiosos conservam os valores das culturas formando as tradições. Os símbolos expressam o incondicionado das histórias e narrativas presentes nestas culturas, fornecendo o fundamento para crenças e costumes. Entretanto, as imagens sagradas e os símbolos religiosos perpassam as épocas da história cultural devido a sua abertura natural e a sua disposição aos valores transcendentes. Imagens e símbolos, portanto, possuem a capacidade de transcender o histórico (por isso Eliade é comumente acusado de anti-historiscista, como tentou demonstrar a tese $O$ 
sagrado e a história: fenômeno religioso e valorização da bistória à luz do anti-bistoricismo de Mircea Eliade, de André Eduardo Guimarães), o temporal e, principalmente, o racional filosófico. Imagens e símbolos pretendem comunicar aquilo que seria impossível de ser comunicado de outra maneira senão metaforicamente (ELIADE, 2004, p. 168-69). A este respeito, no âmbito cristão, imagens e símbolos servem para revelar algo que se passou na Antiguidade e que ainda guarda significado na comunidade religiosa. A exemplo, o uso da cruz,

que simboliza o filho de Deus que está morto. Esta passa a ser, no mínimo, um memorial da fé cristã através da qual um cristão simboliza o centro vivo de sua fé, um Deus encarnado, morto e ressuscitado. Podemos considerar que esta cruz não é, simplesmente, um memorial, mas um objeto sagrado que integra misticamente, magicamente um acontecimento central da vida de Deus e que é, pois, um objeto sagrado que não pode ser manipulado sem o mínimo de precaução ou de preparação. Então, esta cruz se torna algo separado da nossa realidade sensível profana e adentra outro mundo, um mundo regido pelos interditos. A simbolização da cruz não está escrita nesta imagem. Somos nós que, a partir de uma prefiguração da crença, iremos atribuir a esta cruz um valor, um valor que tem uma história. Uma história que fará com que essa imagem visual seja uma porta de entrada em direção ao invisível, porque essa cruz é um meio de fazer parte da vida invisível de Deus neste instante. Todas as religiões, hoje em dia, manipulam este tipo de simbólico (WUNENBURGER, 2009, p. 317).

Podemos inferir com a citação de Wunenburger que a religião usa de imagens e símbolos para, de certo modo, traduzir melhor a economia da troca daquilo que é substituído (ou representado) pelo símbolo. A cruz apresentase como um exemplo prático: apresenta ao homo religiosus uma perspectiva transcendente da vida cotidiana: apresenta uma esfera sagrada diante do ordinário e do profano. A cruz - ou a imagem de uma cruz - entalha, não representa apenas um objeto, mas se torna, pela crença de algo sagrado, que está além daquilo que fenomenologicamente poderíamos falar que é, em uma relação ascendente, para o alto, para uma presença universal despertada pelo símbolo a despeito da ausência implícita no próprio símbolo. Assim, ainda que outros símbolos possam ser comumente usados com o mesmo fim o preenchimento de uma ausência -, imagens de Cristo, arcas da aliança, Menorah, dentre outros ícones, são atribuídos de significados a fim de ultrapassarem o limite da realidade palpável, do tempo e da razão vigente, para a direção de um simbolismo do centro (cf. ELIADE, 2004, p. 28-34): o conteúdo destes símbolos promovem um ser humano integral na sua situação existencial. A integralidade é o fim de todo simbolismo implícito nas narrativas religiosas cujo fundo semântico procura passar dos condicionamentos históricos para a uma vida espiritual aberta pelos símbolos, tornando-a integral. 
A vivência pautada pelo simbólico permeia toda e qualquer religião. $\mathrm{O}$ simbólico é o produto da imaginação e, enquanto tal, oferece um conhecimento primordial pois ele remete a um "ser primordial", isto é, um arquétipo de ser, um modo de existência que contemple todas as variações da vida, incluindo a sua finitude na infinitude para uma pretensão - pelo menos - de um despertar integral e total. Mesmo que o paraíso esteja perdido, segundo Eliade, "as imagens das suas nostalgias, dos seus desejos, dos seus entusiasmos etc., são outras tantas forças que projetam o ser humano historicamente condicionado num mundo espiritual infinitamente mais rico do que o mundo fechado do seu "momento histórico"' (ELIADE, 2004, p. 14). Logo, não se trata da negação do mundo material per se, mas de uma crença na totalidade da vida. A respeito desta crença, apesar de David Hume e Mircea Eliade não serem da mesma tradição filosófica, podemos concluir com Hume:

"Crer é sentir uma impressão imediata dos sentidos ou uma repetição dessa impressão na memória; é a vividez dessa percepção que constitui o primeiro ato do juízo e estabelece o fundamento do raciocínio que formamos com base nela ao traçarmos relações de causa e efeito". A regularidade da experiência permite-nos tirar conclusões que excedem as percepções presentes; pela crença nascida do hábito progressivamente constituído, convertemos a mera repetição de casos de conjunção constante em uma produção de inferências de probabilidade. A passagem do hábito - que abrange, na mente, a união dos casos de conjunção constante na experiência - à crença — ato próprio de conhecimento - é comparável à transição hegeliana da quantidade à qualidade, pela qual simples modificações quantitativas se transformam, em dado momento, em diferenças qualitativas: produzida por certo número de impressões acerca de conjunções passadas, a crença não acrescenta nada à ideia, mas altera o modo pelo qual a mente a concebe, dotando-a de maior força e vividez (VALADARES, 2009, p. 263-64).

Uma aproximação temática das imagens e dos símbolos na religião necessitaria de um método que fosse ao mesmo tempo suficiente e primoroso para a interpretação das imagens e dos símbolos religiosos. Entretanto, anterior a qualquer método, a aproximação mais metódica, a nosso ver, contemplaria as percepções, impressões e ideias pelo fenômeno sensível, gerando, assim, uma linguagem própria expressada em símbolos. Tais símbolos, passíveis de crença e profundidade, mantêm-se até hoje por meio das culturas, das tradições e dos costumes; carregam valores e procuram integrar o ser humano em seu centro, torná-lo integral com certas ações e palavras para preencher o vazio existencial na direção de uma unidade primordial, na tentativa, portanto, de abolir os opostos e as polaridades. Crer é pensar; pensar, leva a sentir; e o sentimento traz uma profundidade ao símbolo que transcende qualquer explicação humana. 


\section{Considerações finais}

O estudo do imaginário religioso começa com variações imaginárias do próprio imaginário. Isso acontece devido a natureza da consciência humana. Desde Platão (que pretendeu delegar às imagens um uso equivocado do saber) até a filosofia Moderna (que depositou na imagem uma nova heurística do saber, como em David Hume, ou uma função servil à razão, como em Immanuel Kant), o trabalho acerca do imaginário fundamenta não apenas a crítica da arte, a estética da imagem e a recepção desses conhecimentos, como também oferece à antropologia e à teologia um outro horizonte de compreensão das ideias religiosas. Filosoficamente, os problemas que o estudo do imaginário coloca são da ordem da origem, dos fundamentos da existência. A perenidade das imagens denuncia a sobrevivência subconsciente dos valores arcaicos preservados nas grandes narrativas fundantes das sociedades, nos símbolos culturais mais agregadores, nas imagens primordiais que constituem o imaginário de uma determinada cultura. Os textos sagrados e suas representatividades, como o relato da criação, o mito do Paraíso Perdido, a imagem do ser humano perfeito, o mistério do Amor Divino ou a salvação final guardam um punhado de ideias elaboradas acerca do sentido da vida e da realidade última. O estudo destas histórias não se limita a descrições técnicas nem em análises estritamente semióticas: conforme declarou Eliade a este respeito, "é a presença das imagens e dos símbolos que conserva as culturas 'abertas" (ELIADE, 2004, p. 168). O arcabouço do conhecimento religioso parte da abertura promovida pelas imagens e pelos símbolos. Completa Eliade a respeito de tal abertura: "as situações-limite do homem são perfeitamente reveladas graças aos símbolos que sustentam estas culturas” (ELIADE, 2004, p. 169). O estudo das imagens e dos símbolos possibilitará a compreensão não apenas da própria imagem ou do próprio símbolo, mas possibilitará a compreensão da existência do sujeito ou de uma comunidade formada pelo simbolismo. Portanto, como aproximação temática e metodológica, propomos a contemplação dos símbolos e das manifestações ficcionais como produtos mais originais de uma determinada comunidade; como as chaves mais profundas para se compreender uma determinada cultura ou uma determinada situação existencial. Afinal, como intuiu Wolfgang Iser a respeito da seriedade com a qual poderíamos assumir as produções culturais, tendo em vista que essas produções dizem respeito aos princípios e às vivências de uma determinada sociedade, "o imaginário de uma cultura se revela em seus produtos ficcionais” (ISER, 2013, p. 41). 


\section{Referências bibliográficas}

AUERBACH, Erich. Mimesis: a representação da realidade na literatura ocidental. São Paulo: Perspectiva, 2013.

BACHELARD, Gaston. A água e os sonhos: ensaio sobre a imaginação da matéria. São Paulo: Martins Fontes, 1998.

CAMARGO, Marcos Henrique. Formas diabólicas: ensaios sobre cognição estética. Londrina: Syntagma, 2017.

CASSIRER, Ernest. Esencia y efecto del concepto de símbolo. México, D.C.: Fondo de Cultura Económica, 1975.

CASSIRER, Ernest. Linguagem e mito. São Paulo: Perspectiva, 1985.

CONTE, Jaimir. A natureza da filosofia de Hume. In: Anais do III Colóquio Internacional de Metafísica. Natal, RN: Editora da UFRN, 2010.

CROMBIE, Ian M. Plato's Doctrines. Vol. 2. London: Routledge \& Kegan Paul, 1967.

DOSSE, François. O império do sentido: a humanização das ciências humanas. São Paulo: Editora da Unesp, 2018.

DURAND, Gilbert. As estruturas antropológicas do imaginário: introdução à Arquetipologia Geral. São Paulo: Martins Fontes, 2013.

DURAND, Gilbert. A imaginação simbólica. Lisboa: Edições 70, 1993.

DURAND, Gilbert. Champs de l'imaginaire. Textes réunis para Danièle Chauvin. Grenoble: Ellug, 1996.

DURAND, Gilbert. O imaginário: ensaio acerca das ciências e da filosofia da imagem. Rio de Janeiro: DIFEL, 1998.

ELIADE, Mircea. Autobiography, Volume 1: 1907-1937, Journey East, Journey West.

Chicago: University of Chicago Press, 1990.

ELIADE, Mircea. Autobiography, Volume 2: 1937-1960, Exile’s Odyssey. Chicago: University of Chicago Press, 1988.

ELIADE, Mircea. Methodological remarks on the study of religious symbolism.

In: ELIADE, Mircea; KITAGAWA, Joseph M. (orgs.). History of Religions: essays in methodology. Chicago: University of Chicago Press, 1959.

ELIADE, Mircea. Imagens e simbolos. São Paulo: Martins Fontes, 2004.

ELIADE, Mircea. Journal III - 1970-1978. Chicago: University of Chicago Press. 1989.

ELIADE, Mircea. Mefistófeles e o andrógino: comportamentos religiosos e valores espirituais não-europeus. São Paulo: Martins Fontes, 1999.

ELIADE, Mircea. Mito e realidade. São Paulo: Perspectiva, 2006.

ELIADE, Mircea. Mitos, sonhos e mistérios. Lisboa: Edições 70. 1957. (Perspectivas do homem, v. 32).

ELIADE, Mircea. O mito do eterno retorno. Lisboa: Edições 70, 1969. (Perspectivas do homem, v. 32).

ELIADE, Mircea. O sagrado e o profano. São Paulo: Martins Fontes, 2001. 
FERREIRA, Amauri Carlos; SILVEIRA, Luiz Henrique Lemos. Do Círculo de Eranos à construção do simbólico em Carl Gustav Jung. Psicologia USP, v. 26, n. 2, p. 259-268, 2015. [cited 2020-07-04] <http://www.scielo.br/scielo.php?script=sci_arttext\&pid=S010365642015000200259\&lng=en\&nrm=iso >. ISSN 1678-5177. http://dx.doi. org/10.1590/0103-656420140002.

FLUSSER, Vilém. Filosofia da caixa preta: ensaios para uma futura filosofia da fotografia. Rio de Janeiro: Sinergia Relume Dumará, 2009.

FRYE, Northrop. O código dos códigos: a Bíblia e a literatura. São Paulo: Boitempo, 2004. HADDAD, Alice Bitencourt. A visão sensível como imagem da visão dos inteligíveis. Trans/Form/Ação, v. 35, n. 3, p. 3-20, 2012. [cited 2020-07-04] <http://www.scielo.br/ scielo.php?script $=$ sci_arttext\&pid $=\mathrm{S} 0101-31732012000300002 \& \operatorname{lng}=\mathrm{en} \& \mathrm{nrm}=\mathrm{iso}>$. ISSN 0101-3173. http://dx.doi.org/10.1590/S0101-31732012000300002.

HIGUET, Etienne. Interpretação das imagens na teologia nas ciências da religião. In: NOGUEIRA, Paulo (org.). Linguagens da Religião. São Paulo: Paulinas, 2013.

HUME, David. Investigações sobre o entendimento bumano e sobre os princípios da moral. Trad. José Oscar de Almeida Marques. São Paulo: Editora da UNESP, 2004.

ISER, Wolfgang. O fictício e o imaginário: perspectivas de uma antropologia literária. Rio de Janeiro: EdUERJ, 2013.

ISER, W. O fictício e o imaginário. In: ROCHA, J.C.C. Teoria da fição: indagações à obra de Wolfgang Iser. Rio de Janeiro: EdUERJ, 1999. Pp.67-77.

JUNG, Carl. O bomem e seus simbolos. Rio de Janeiro: Nova Fronteira, 1977.

KITAGAWA, Joseph M. (org). History of Religions: essays in methodology. Chicago: University of Chicago Press, 1959.

TILLICH, Paul. Filosofía de la Religión. Buenos Aires: Megápolis, 1973.

TILLICH, Paul. Systematic Theology. Vol. 1. Chicago: University of Chicago Press, 1973. VALADARES, Alexandre Arbex. A teoria da causalidade imaginária na filosofia de Hume. In: Kriterion, Belo Horizonte, v. 50, n. 119, p. 251-268, 2009.

WUNENBURGER, Jean-Jacques. As formas de expressão do imaginário e as estruturas paradoxais da linguagem simbólica das imagens. Revista Educere et Educare, v. 8, n. 16, p. 311-319, jul./dez. 2013.

ZILLES, Urbano. Adorar on venerar imagens?. Porto Alegre: Editora da PUC-RS, 2007.

Submetido em: 7-7-2020

Aceito em: 23-9-2020 